\title{
Double-Skin Facades in Exalted Buildings: A Solution for Sustainable Development
}

\author{
Ali Khaki \\ Assistant Professor in Department of Architecture, Shahid Rajaee Teacher Training University \\ Tehran, Iran, khaki@srttu.edu \\ Ali Sadeghi Habib Abad
}

Master of Architecture, Shahid Rajaee Teacher Training University, Tehran, Iran, a.sadeghi@srttu.edu

\section{Doi:10.5901/mjss.2015.v6n6s6p237}

\begin{abstract}
In recent years, a new method called Double-skin facades has been innovated in European countries, especially Germany, Netherlands and England. With 30 percent save in energy consumption, providing proper air-conditioning in building, significant reduction of unpleasant noises and transparent design, this facade has truly provided convenience for the residents, and have gained a lot of popularity. Active facade (Double-skin facades) is a facade that cover on or several floor of building with multiple transparent covers. These layers can either weatherproof or not. The application of sustainable development in architecture has brought about new topics known as sustainable architecture, ecology architecture, green architecture and environment architecture which have similar meanings and all relate to the type of architecture that is compatible with the environment. One of the most important aspects of sustainable development is in fact sustainable architecture, as more than half of greenhouse gases are created in residential places. considering that the amount of greenhouse gases is developing countries is more than that of developed countries, the issue sustainability in architecture becomes more significant. By investigating double-skin facades and their function, this study is attempting to present a solution to introduce this facade as a replacement for facades of exalted buildings, and to take leap for the reservation of national treasure for future generations.
\end{abstract}

Keywords: double-skin facade, sustainable architecture, national resources, conservation of environment, exalted buildings

\section{Introduction}

One of the three important domain targeted by sustainable deployment is environmental issues. The task of architects in this field is greatly significant; as they are, either directly or indirectly, responsible of $75 \%$ of weather changes (Rodgers, 2005). Sustainable development in relation with buildings or environment is often called sustainable structure or sustainable construction. The issue of buildings and environment are considered two key domains in global sustainable development (CIB, 1999).

After the energy crisis of the 70s, the idea of revolutionizing façade structure has been introduced. The reason behind this idea is achieving optimum thermal convenience in different climates along with optimum use of daylight as well as energy consumption. Utilizing high performance glasses specially designed to perform against sun light and energy ( $\mathrm{V}$-Cool glasses) and double-skin facades are originated from this idea.

Facades have traditionally served as a barrier between internal space and climate conditions of outside and its performance evaluation is undertaken based on the ability to distinguish internal and external spaces. Meanwhile, new design ideas regard the façade of building as a barrier to balance external and internal spaces. (McClintock, 1997). One the functions of façade is preservation of building against atmospheric conditions and prevention of energy transfers. For this purpose, various solutions like using internal and external canopies can contribute (Hamza, 2008). Hensen et al. (2002), showed that simulations of double-skin façades include factors like temperature and air fluctuations; with proper evaluation and analysis of these factors, the thermal load of building can be controlled.

\section{Methodology}

In this study, in addition to reviewing previous researches in the field of sustainable development, the method is descriptive-analytical and discussions are addressed through studying the literature, article and documents regarding double0skin façades, as well as sustainable engineering, and effective parameters in building structures aimed at sustainable architecture are discovered. 


\section{Hypothesis}

By studying and analyzing effective parameters in building structures, the following hypothesis can be introduced:

* With utilizing the principles of double-skin façade in exalted buildings and employing smart methods, optimum options for these buildings can be identified to address sustainable development

\section{The Significance of the Study}

Basically, the dangers that threaten environment have different perspectives. Air contaminants, water contaminants, soil drifting, and deforestation of jungles are among factors for pollution. The earth we live on is too old to be able to live naturally without the help of its residents. Hence, environment and its protection is a priority on the agenda of authorities in many countries. By hearing the issue of sustainable development, Fans of environment primarily attend the preservation of national resources and try to concentrate on creating harmony between human and nature. It is fortunate that many people and group deal with issue with long-term approaches, and by considering future generations, they are seeking a way to balance the interaction of human and nature, as natural resources don't belong to any specific generation, and hence it should be used in such way that the future generation of this nation can benefit from it.

\section{Sustainable Development}

The term sustainable development was first coined in 1970s about environment and development. Sustainable development is a process to achieve stability in every activity requiring resources and fast and consistent replacements. Sustainable development intends to achieve continuous development along with economic growth and human development. Alan Fricker considers sustainability as a perspective to future that actually is the route which is based on ethical principles (Munier, 2005).

A set of definitions about sustainable development can be described as follows:

* Addressing the needs of future generations providing current needs without negative effects on future generation)

* Attending to tolerance capability of ecosystems (improvement of human life with supporting ecosystem)

* Maintaining Wealth And Natural resources (protecting natural resources as an environmental asset)

* Maintenance and Promotion of systems (Along With Maintenance And promotion of diversity and production)

* Stabilizing human life (keeping the power of system to stabilize people's life)

* Protecting the environment

* Integrating protection and development as a general approach to achieve fundamental and social needs of humans, social justice, protecting the consistency of ecology (Azizi, 2006).

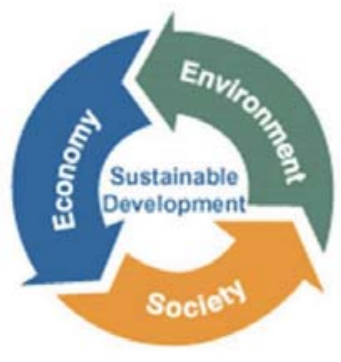

Figure 1: three main elements of sustainable development

\section{Sustainable Architecture}

During the past century, valuable achievements and evolution have taken place in architecture and environment which has also created many issue, and it can be said that, in early 21 century, the world has reached to an unsustainable development with characteristics such as population growth, over-consumption, and unbalanced distribution of resources. The term sustainability has various meanings and its definition is not clear in architecture, but mostly covers issues 
surrounding earth and nature preservation. Sustainable development is primality concerned with environmental issues.

From the viewpoint of Richard Rogers, sustainable architected intend to face the need of future, without destroying the remaining resources of future generations. In case of buildings, sustainable design refers to flexibility, lone lifetime, stable stagnancy, efficiency of resources, and minimum energy (Rogers, 2007). The following principle should be complied for a building to be able to be classified as sustainable (Ghiasvand, 2006):

1. Conservation of energy

2. Harmony with climate

3. Reduction of new resources

4. Providing the need of residents

5. Consistency with site

6. Holism

7. Stability stagnancy (Khaki, 1999): according to this principle which is based on geometrical structures, the elements of buildings should be highly efficient, and by choosing proper forms and based on geometry, the aesthetics of buildings are greatly improved.

All the principles of architecture should lead to a better environment in a complete cycle (Vale, 1996).

\section{The Importance of Environment and Resources and their Preservation}

The nature is a God-given gift that is made from creatures, resources and the conditions with which every living creature can live. The pollution of environment affects the quality and natural cycles and have devastating consequences for the lives of humans, animals, plant and buildings. In today world, the issue of pollution is one of the most critical problems of human life. Nature has been created for the survival of humankind, and there is an indispensable relation between human and nature. Educating people in this field is a responsibility that should be seriously followed. Otherwise, in near future, there remains no environment to tend to.

\section{Double-skin Façade}

Double-skin façade is distinguished from other facades with having at least two inter-atmospheric layers between living space and environment. In the interval, a route is considered for air flow. The ventilation of middle air can be either natural or mechanical. Glasses can be double glazed or single glazed. To preserve and keep heat in colder periods, canopies are deployed in inner part of the façade. In other terms, double-skin facades are a crust for buildings that are consisted of two layers (internal and external) made from glass or other material that are separated using windows with the ability to ventilate air (figure 2) (Azarbayjani, 2010).

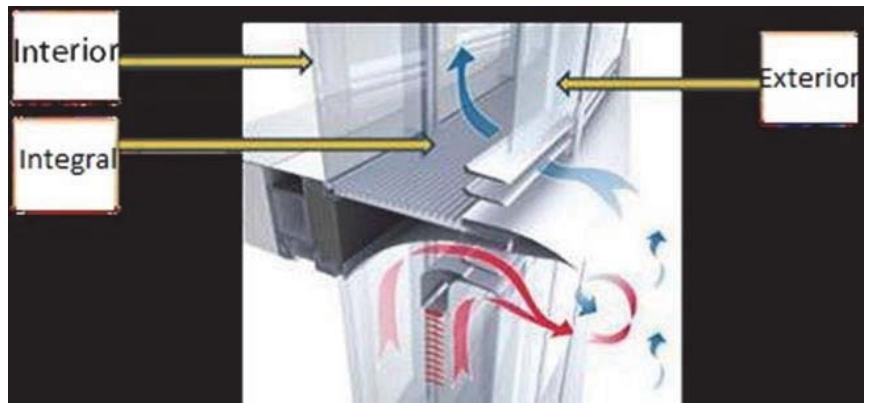

Figure 2: Elements of Double-skin Façade

Double-skin façade is an architectural idea built with two walls separated with an air layer. This container has the task of preserving sun heat and creating greenhouse effect in winter. Hence, the issue of thermal convenience and the quality of internal air is improved, while the thermal load is decreased (Hashemi, 2010). The development of this technology started from colder regions, and has been widely distributed since 1980 in Europe, North America and Japan (Hamza, 2008). Recently, with rapid economic development, new buildings are constructed with double0skin façades in areas with very hot summers and cold winters (Zhou, 2010). 


\section{Types of Double-skin Façades}

Double-skin façades can be classified based on internal structure of façade (Poirazis, 2004), method of air entrance and exit (Gratia, 2007), and type of ventilation (Poirazis, 2008):

* Based on internal structure of façade: consisted of 4 types:

1. window box

2. shaft-box façade

3. corridor façade

4. multistory façade

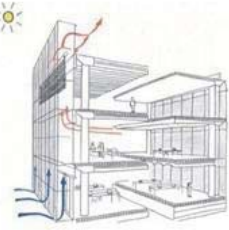

Multistory

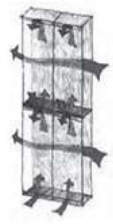

corridor

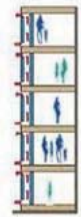

1

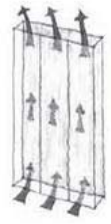

shaft-box
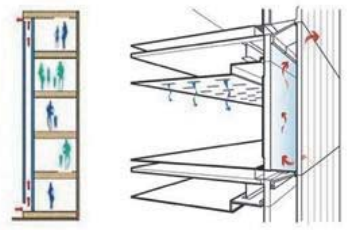

window box

Figure 3: Types of double-skin façades based on integral structure

* Based on method of air entrance and exit (Gratia, 2007):

1. Internal air curtain: air is entered from inside the façade and return to inside

2. External air curtain: Air is entered from outside and returns outside. In this case, natural air-conditioning occur.

3. Static air buffer system: no ventilation occurs and as a barrier, a thermal stability is achieved.

4. Supply air: Air is entered from inside and returns outside.

5. Exhaust air: Air is entered from outside and returns inside

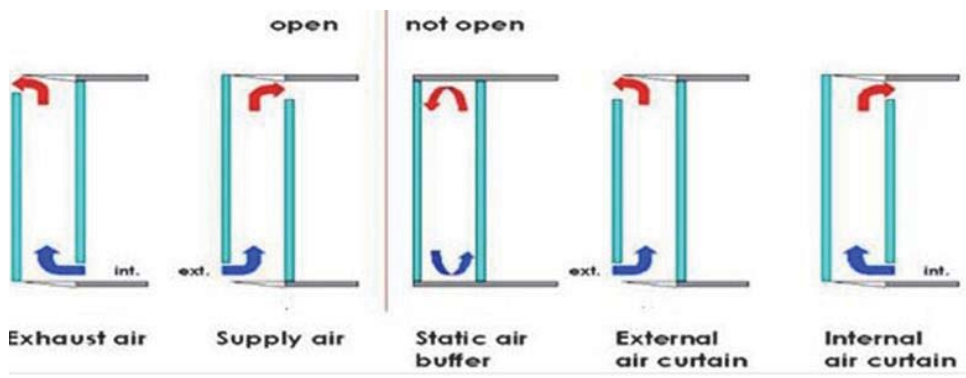

Figure 4: Air Flow in double-skin façade (Hasse, 2009)

\section{Advantages of Double-skin Facades}

The following are among advantages of double-skin facades (Poirazis, 2004):

Proper air-conditioning, noise reduction, thermal barrier for summer and winter, energy saving and reduction of environmental damages, reduction of wind pressure, achieving transparency in design, natural conditioning

Natural air-conditioning makes air flow in the space which can be used for cooling. Double view façade allows the condition of air which is controllable by residents. Also, the intake of sunlight can be controlled which is possible through canopies installed in air channels. These canopies can absorb and lessen radiations inflicted by sun. Air channels can also serve for the same purpose. Double-skin façades also reduce thermal wastes. It should be noted that through a large surface of glass, double-skin facades increase the light intake and thus reduces the need for electrical lighting and energies. 


\section{Discussion and Conclusion}

To have a better understanding of theoretical principles (sustainable design), it is fitting to review the view of experts on the matter of sustainable designing principles. Every principle of sustainability and localized design can explore the relation of artificial environments and the nature. These principles explore the mutual correlation and interaction between human environments and natural systems, and follow the chain of effects of design decisions on the environment. In addition to providing proper lighting for exalted buildings with HVAC system, Double-skin facades have the capability to provide the peace and convenience of residents and save the cost of energy consumption. Double-skin facades is one of the initiative that can configure parameters like heat, coldness, and noises, and provide the convenience of residents without losing energy. In addition to the advantages introduced in the article, these facades can present beautiful forms to body of buildings in term of architectural aesthetics, and direct architects to creating beautiful and flexible facades; although this issue is out of the scope of this article.
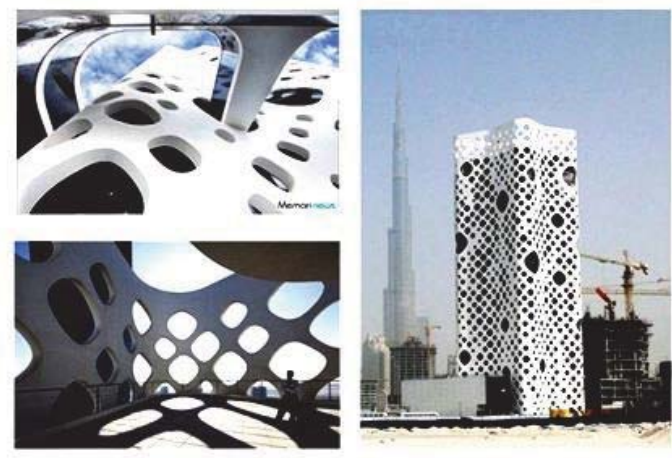

Figure 5: 0-14 tower in Dubai, United Arabic Emirates

\section{References}

Ghiasvand, Javad, 2006, interaction of architecture and new sustainable energies, journal of road and construction, volume 38.

Azizi, Mohammad Mehdi, 2006, sustainable residential district: case study of Narmak, beautiful arts, v. 27, p. 37.

Khaki, Ali, 1999, sustainability stagnancy and the most important element of sustainable architecture, Russian journal of department of architecture, v. 173.

Zhou, J., \& Chen, C. (2010). A review on applying ventilated double-skin facade to buildings in hot-summer. Renewable and Sustainable Energy Reviews, 14(4), 1321-1328.

Vale, B. and R. Value, (1996) Green Architecture: Design for a Sustainable Future, London: Thames \& Hudson Ltd.

Rogers, Richard (2007), Sustainability, www.richardrogers.co.uk.

Rogers, Richard (2005), Action for Sustainability, JA (Japanese Architecture), No. 60, p.129.

poirazis, h. (2008). single and double skin glazed office buildings.

Poirazis, H. (2004). Double skin facades for office buildings. Department of Construction and Architecture, Division of Energy and Building Design Lund Institute of Technology.

Munier, Nolberto (2005), Introduction to Sustainability: Road to a Better Future, The Netherlands: Springer.

McClintock, M., \& Perry, J. 1997. "The Challenge of 'Green' Buildings in Asia". In: International Conference of Building Envelope Systems and Technologies (ICBEST). Bath University, UK.

Hensen, J., Bartak, M., \& Drkal, F. 2002. Modeling and Simulation of a Double-Skin Façade System. ASHRAE Transactions .p 108.

Hashemi, N., Fayaz, R., \& Sarshar, S. (2010). Thermal behaviour of a ventilated double skin facade in hot arid climate. Energy and Buildings, 42(10), 1823-1832.

Hamza, N. 2008. "Double versus single skin facades in hot ardi areas". Energy and buildings. 40. Pp 240-248.

Hamza, N. (2008). Double versus single skin facades in hot arid areas. Energy and buildings, 240-248.

Haase, m., Marques da Silva, f., \& Amato, a. (2009). Simulation of ventilated facades in hot and humid climates. 41, 361-373.

Gratia , E., \& De Herde, A. (2007). The most efficient position of shading devices in a double-skin facade. Energy and Buildings, 39(3), 364-373.

CIB, (1999), Agenda 21 on Sustainable Construction, Rotterdam: CIB Report Publication 237.

Azarbayjani, m. (2010). Beyond Arrows: Energy Performance of a New, Naturally Ventilated Double-Skin Facade Configuration for a High-Rise Office Building in Chicago(Doctoral dissertation). 